\title{
QUANTITATIVE EASING AS THE MAIN INSTRUMENT OF UNCONVENTIONAL MONETARY POLICY
}

\author{
Halyna Alekseievska ${ }^{1}$, Anzor Mumladze ${ }^{2}$
}

\begin{abstract}
After the fall of Lehman Brothers in September 2008, the financial crisis turned into a global crisis and had a negative impact on the real economy. During the crisis, there has been a significant decrease in key macroeconomic indicators, such as GDP, short-term interest rates, unemployment and inflation. The GDP growth rate had taken a negative value in developed countries. Inflation was below 1 percent, and deflation was observed in Japan, which in turn slowed down economic development. Central banks responded to the crisis with a change in interest rates, but this was not enough to calm financial markets and improve the real economy. Most central banks have developed many new monetary policy tools, including communication strategies, credit policies, and large asset purchases. These new measures are often called "unconventional" monetary policies. The purpose of the article is to study quantitative easing as one of the unconventional measures of monetary policy. Methodology. The article uses general scientific and special methods: generalization, systematization, economic and statistical analysis, graphic and comparison methods. This allowed us to study the theoretical foundations of the quantitative easing policy, determine the economic background for these measures application, analyze the development stages and the basic rules of functioning policy. The quantitative easing policies usage was also examined on the examples of the Federal Reserve, the European Central Bank, the Bank of England and the Bank of Japan. Results. The main trends and economic conditions, under which these methods can be used in future, were identified using an analysis of the quantitative easing application background. The policy's main components analysis provides a clear understanding of the quantitative easing essence. As a result of the unconventional monetary policy usage, there has been a significant expansion of the USA, Japan and the Eurozone central banks' balances, which amounts to more than 10 trillion USD. Due to this process, central banks have become key bondholders. Practical meaning. The given results analysis will determine that kind of unconventional monetary policy effectiveness and the possible consequences of a significant increase in the central banks' balance sheet assets. Value/originality. In the article, the conditions, under which unconventional monetary policy has been applied, are systematized and the four central banks' quantitative easing policy is compared.
\end{abstract}

Key words: monetary policy, non-traditional monetary policy, quantitative easing, Central banks

JEL Classification: E40, E50, F44, G15

\section{Introduction}

At the usual times, central banks use the overnight interest rate on the interbank market as their main policy tool. In the interbank market, banks lend and borrow bank reserves from one another. Central banks can control this interest rate by adjusting the level of reserves either upward or downward.

Commonly, the central bank makes this adjustment in accordance with the general level of reserves corresponding to the minimum reserve requirements. But the recent financial crisis has demonstrated the failure of traditional methods. And in response to the global financial crisis, the central banks of many countries have taken unprecedented risks countering measures to stabilize prices.

As policy rates are approaching to zero lower bounds, large-scale asset purchases, often referred to as "quantitative easing" (QE), have replaced interest rates as the main policy tool.

\footnotetext{
Corresponding author:

${ }^{1}$ Odessa I.I. Mechnikov National University, Ukraine.

E-mail: g.alex@onu.edu.ua

ORCID: https://orcid.org/0000-0002-6708-0098

ResearcherID: AAM-4387-2020

${ }^{2}$ Odessa I. I. Mechnikov National University, Ukraine.

E-mail: anzor.mumladze@billiontons.eu

ORCID: https://orcid.org/0000-0003-3065-8172
} 
And to date, such an innovative method of monetary policy remains urgent for its study and analysis of effectiveness and application possibility in the future.

Unconventional monetary policy, its influence and effectiveness is an object of study in the works of many scientists. In particular, an article by Brett W. Fowley and Christopher J. Neely (2013) describes the circumstances and motives of quantitative easing programs for the Federal Reserve System, the Bank of England, the European Central Bank and the Bank of Japan during the recent financial crisis.

Giovanni Dell'Ariccia, Pau Rabanal, Damiano Sandri (2018) in their work investigate how quantitative easing and negative interest rate policies work in theory, and some of their potential side effects. They also consider the European Central Bank, Bank of England and the Bank of Japan unconventional monetary policy implementation, including an analysis of how central banks reacted to the crisis, and data on the unconventional monetary policy measures impact.

Rodrigo Fernandez, Pablo Bortz and Nicholas Seolla (2018) assess the European monetary policy impact on the developing countries' economies.

Andrei Filardo and Jochi Nakajima (2018) are exploring whether alternative methods of monetary policy have become less effective in stimulating the economy in the conditions of constantly low interest rates. This article addresses this issue for the United States, the United Kingdom, the euro area, and Japan.

Haldane A., Sklar M. R., Wieladek T., Young C. (2016) study the historical development of quantitative easing policy in their work. They examine international data on the impact of this policy on financial markets and economic activity. The authors believe that the expansion of the balance sheet of the central bank has had a significant impact on the financial markets and the economy. They also found that the US has evidence that QE performance may change over time depending on the state of the economy and the liquidity of the financial system. $\mathrm{QE}$ can have strong cross-border effects, acting mainly through financial channels.

Mathias Neuenkirchen (2016) uses a comparison approach to examine the impact of the Bank of England's asset purchase program on macroeconomic performance in the UK. And it has been shown that quantitative easing has a significant impact on macroeconomic performance.
In his study, Philip Andrade and other authors (2016) analyzes the impact of the European Central Bank's Extended Asset Purchasing Program (APP) on the return on long-term securities and macroeconomic indicators, as well as characterizing its transfer channels.

The purpose of this research is to study the essence of unconventional monetary policy methods based on the consideration of quantitative easing (QE).

\section{Background of QE}

In 2008, the world had the biggest financial crisis since the Great Depression. This recession was caused by the explosion of the real estate bubble, leading large companies such as Lehman Brothers Holding and Bear Stearns Companies to go bankrupt. For 18 months, the US economy was in decline, therefore, it had an impact on the global economy. Economic activity in the G7 countries declined by more than 5\%. The European Union ended up in a debt crisis. The European debt crisis has arisen because of the main problem: the fact that 19 euro area member countries had a common currency. This meant that any monetary policy initiated by the ECB was applied to each country, despite the different economic situation in the region. At the beginning of 2010, markets admitted a mistake, considering all countries in the euro area equally safe (Martin, 2012).

The figure below shows the percentage change in GDP growth for the leading economies of the world since 2000. As you can see in 2008-2009 the period of recession, the indicator takes a negative value.

By the end of 2008, the delayed indirect consequences of the collapse of housing prices in 2006 led to the fact that the financial markets ceased to function, the decline in production and shortterm rates approached zero. Figure 2 shows the convergence of policy rates to zero lower bounds at the end of 2008 and the beginning of 2009.

Another indicator of the crisis in the economy is the unemployment rate. From 2009 to 2013, it is growing every year, and then the trend is declining.

And the most important problem for developed economies is low inflation, or even as can be seen in Figure 4, for example, Japan's deflationary processes. In conditions of low inflation, companies and households can significantly reduce mediumterm inflation expectations, which will create a deflationary spiral: falling demand and deflation will feed each other. In this case, real interest rates 


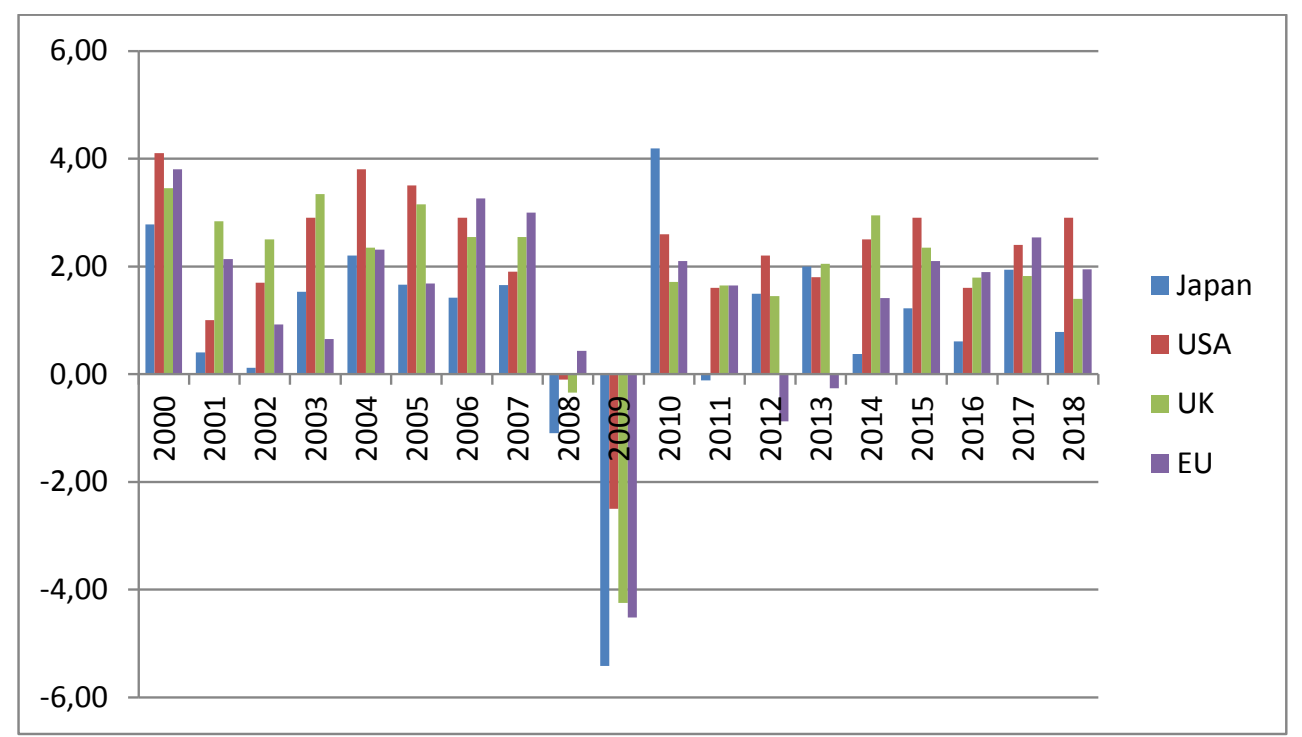

Figure 1. GDP growth (\%)

Source: $[I M F]$

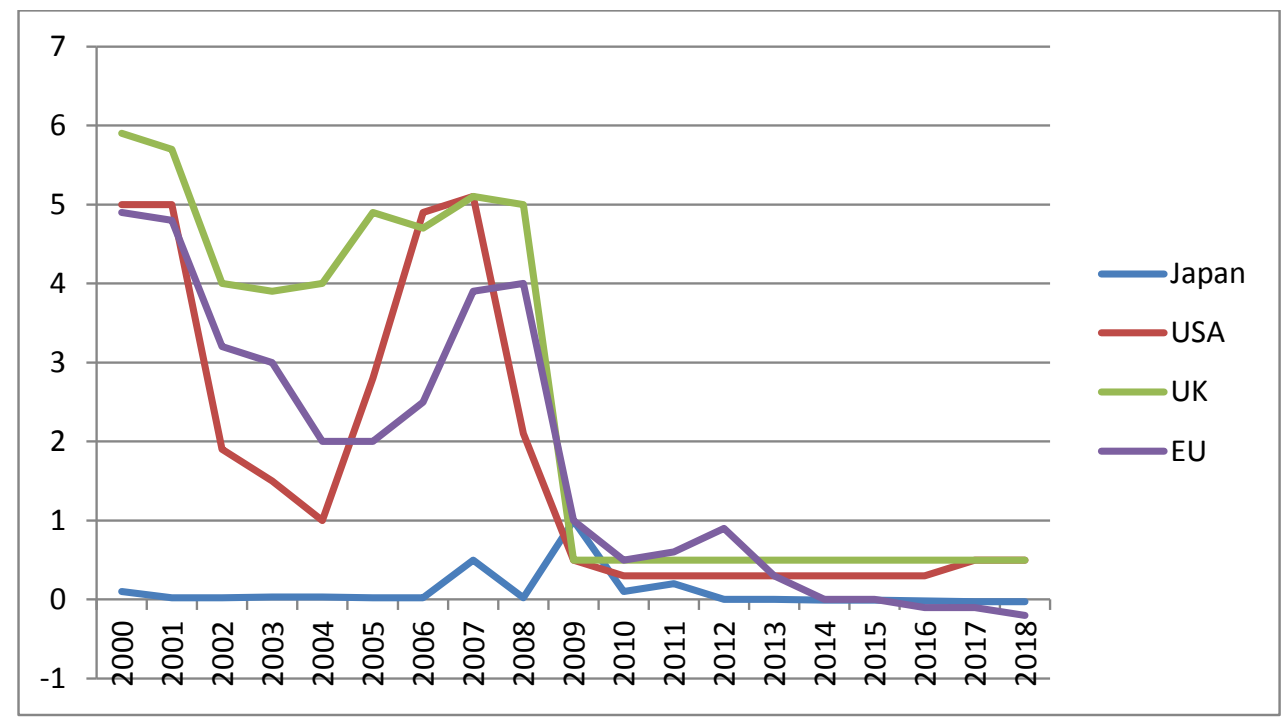

Figure 2. Global interest rates (\%)

Source: $[I M F]$

cannot be reduced to levels that contributed to full employment. Companies that need to cut costs, rather than lower salaries, are more likely to lay off employees. The cost of debt servicing for borrowers will increase. All this will further undermine demand. Thus, low inflation slows economic growth.

In such conditions, low interest rates, inflation, rising unemployment during the crisis period, traditional monetary policy measures have shown their failure. Since standard monetary policy did not stimulate the economy around the world, several countries chose to introduce unconventional methods, one of which is quantitative easing.

\section{Quantitative easing}

Quantitative easing can be described as the purchase of bonds and other debt instruments by central banks. This is an exchange between central banks and other financial intermediaries, such as institutional investors. The goal of QE is to stimulate the country's economy by replacing assets held by financial institutions, such as government debt, corporate bonds and mortgage-backed 


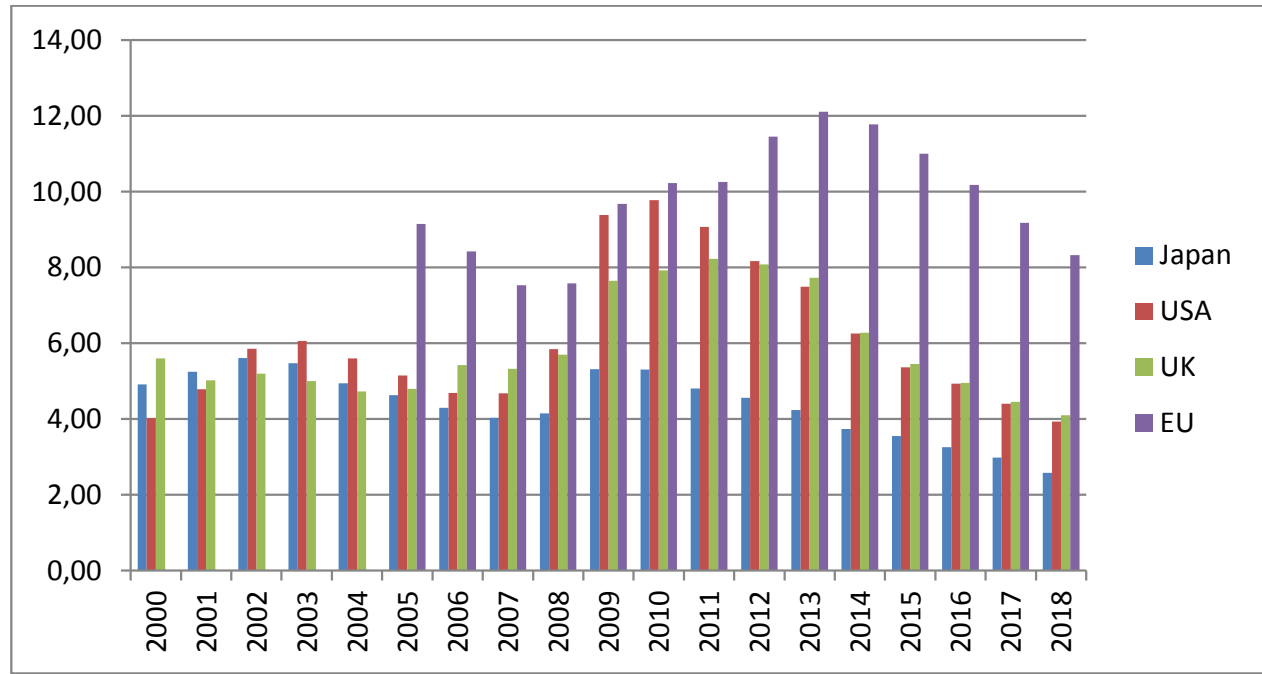

Figure 3. Unemployment rate (\%)

Source: $[I M F]$

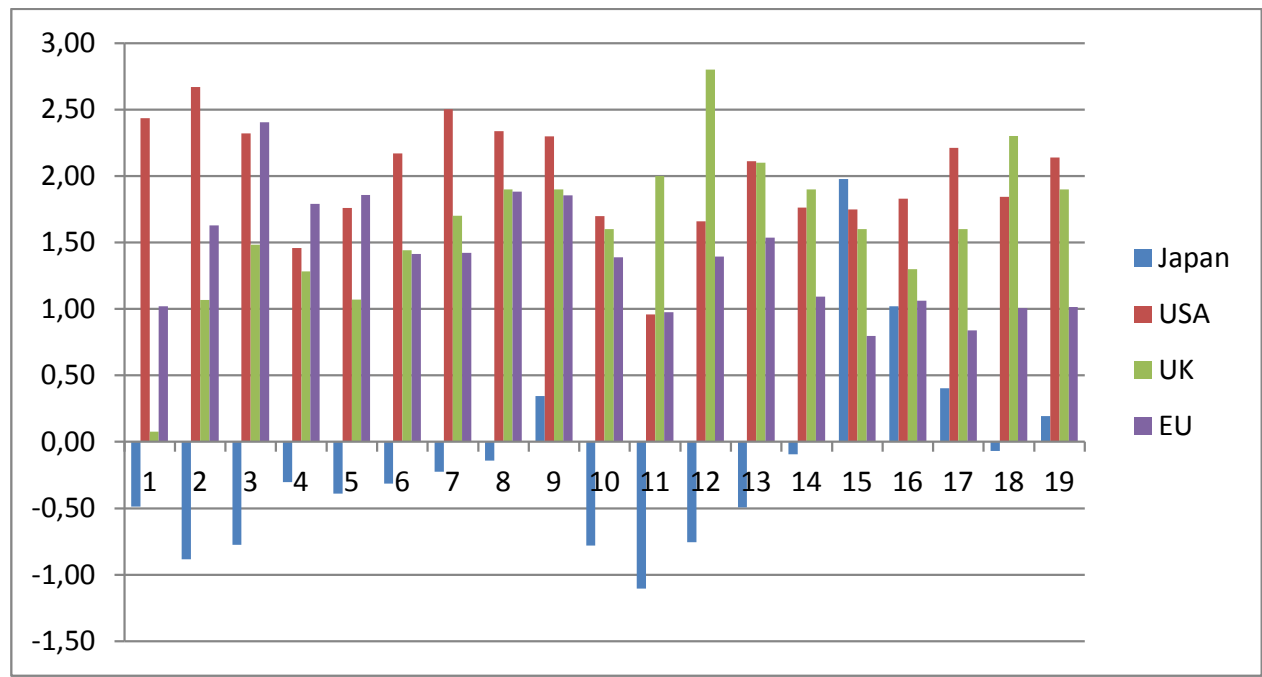

Figure 4. Inflation rate (\%)

Source: $[I M F]$

securities, with cash generated through the process. Theoretically, this process has no limitations, or, more precisely, the only theoretical limit is the stock of existing assets. In modern monetary systems, the central bank is a monopoly supplier of bank reserves or banknotes, two components of the monetary base. Obviously, there are legal restrictions on assets, which a central bank can buy.

Supporters of QE suggest that financial institutions such as banks and pension funds act as channels for liquidity transfer. This happens in the process of the so-called "portfolio rebalancing". When the central bank buys assets and pays for them, creating bank reserves, the composition of the total portfolio of publicly owned financial assets changes. It is this ability of the central bank to unilaterally change the composition of the public total portfolio, which allows $\mathrm{QE}$ to create easier financial conditions. Thus, theoretically and all other things being equal, QE should lead to a (slightly) lower yield on government bonds, a narrower spread of corporate bonds, higher stock prices and a weaker national currency.

All these asset price movements are aimed at creating easier financial terms that are more conducive to stimulating an increased level of economic activity. Such a portfolio rebalancing leads to a shift towards higher risk assets, which, 
in turn, ultimately leads to an increase in company investment and household consumption, and therefore stimulates the economy.

QE is one of the things that central banks do or can do when they have exhausted their usual interest rate measurements. Just as they lowered their discount rate to or close to zero - "pegging to zero," but still need further monetary policy easing to achieve their goals, usually these are complementary to the goals of a low but stable inflation and an economy working on full power or close to it. QE allows us to think about expanding interest rate easing at the zero bound.

QE may be important for inflation targeting. In the inflation targeting mode, the central bank tries to achieve a low but stable inflation rate, which is usually equals $2 \%$. For this purpose, two types of instruments are required: those that tighten financial conditions if inflation threatens to constantly exceed $2 \%$, and those that ease financial conditions if inflation threatens to be below 2\% sequentially. In the first case, the central bank has a tool that it can use indefinitely to try to tighten financial conditions: a short-term interest rate. You can always achieve a sufficiently high interest rate, which tightens financial conditions sufficiently to slow down the economy and reduce inflation.

But in the latter case, there is a problem: the central bank cannot use the short-term interest rate in an unlimited way to try to weaken the financial conditions in order to prevent too low inflation fall or its direct deflation. QE, however, provides the central bank with a similar tool for unlimited ability to cut interest rates. Generally, the central bank can expand its balance indefinitely by purchasing assets which belong to the private sector, or, in case of urgency, debt securities issued directly by the government.

Also, many scientists, economists, politicians and world figures speak of quantitative easing positive results as well as of the potential threats and weaknesses of this method. Consider the main ones:

1. Advantages and beneficial effects

- The lending increase. Due to the increase in funds for the account of the assets purchase by the central bank, commercial banks will issue more loans.

- Borrowing increase: consumers and enterprises are more likely to take on new debts at low interest rates.

- Expenses increase. Consumers will increase their spending as all new loans and borrowings bring more money. With lower interest rates, leaving money in savings is not so attractive.
- Job growth: when enterprises gain access to more capital through loans and sell more on account of rising consumer spending, they are able to expand their activities and hire more employees.

2. Potential disadvantages and negative effect - Inflation: the money supply increase caused by QE naturally creates inflation. Product competition will increase because more money is circulating, but there is no increase in the supply of goods. The higher the demand, the higher the price. If not managed properly, inflation can increase rapidly, which will lead to hyperinflation.

- There is no forced lending: in QE, commercial banks must use the money they receive from the central bank to offer more loans. But there is nothing in this process that would require this from them. For example, when QE was originally used in the United States after the 2008 financial crisis, many banks kept their newfound wealth instead of distributing it.

- Debt increase. The borrowing benefits increase can lead to the fact that enterprises and consumers will borrow more than they can afford, which may have negative consequences for the economy.

\section{Examples of QE application}

In the framework of quantitative easing or $\mathrm{QE}$, the central bank expands its balance sheet by acquiring assets that are paid for through reserves. The starting point will be a situation where the reserve level is at the minimum required level, the central bank conducting QE will create a large amount of excess reserves. This can be reflected in changes in central bank balances (see Figure 5).

The first monetary policy experiment, known as "quantitative easing," began in 2001, when Japan's GDP growth rate slowed significantly. After several open-market operations by the Bank of Japan aimed at reducing interest rates to zero, the Central Bank focused its attention on the commercial banks' current account, which stood at around 1 trillion yen in 2001. By 2005, the balance had grown to 35 trillion yen. A soft monetary policy in Japan helped stimulate the economy but proved unable to cope with deflation (see Figure 4). And after the 2008 crisis, the Bank of Japan has launched programs it calls "quantitative and qualitative easing." In 2010, the Bank of Japan again began planning new measures to stimulate the economy and inflation. $\mathrm{He}$ lowered the interest rate from $0.1 \%$ to $0-0.1 \%$ and began buying Japanese government and corporate bonds, this policy is called "Abenomics". 


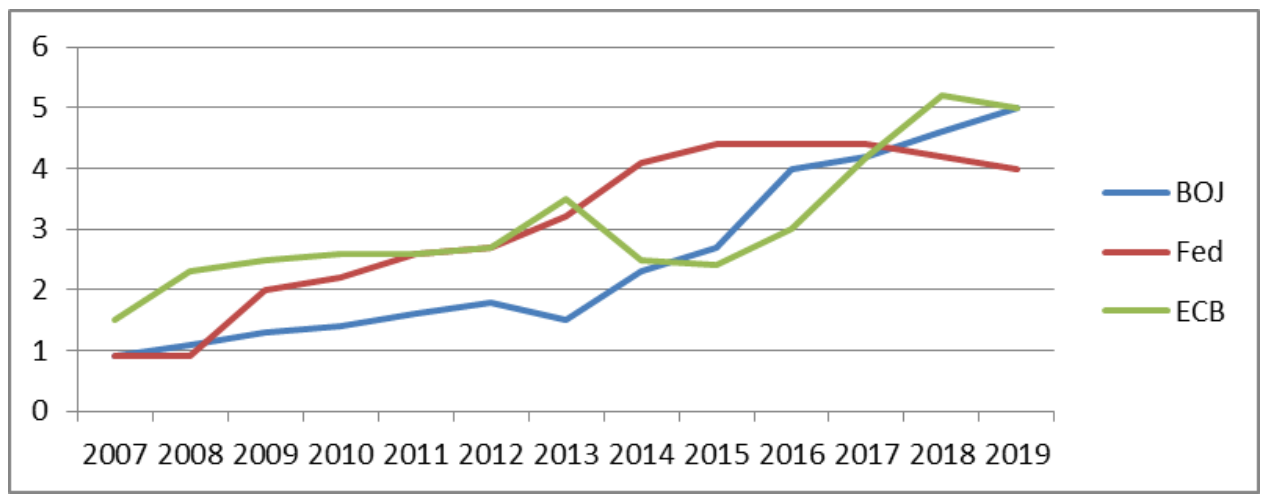

Figure 5. Total assets of large central banks

Source: [Yardeni Research]

A new generation of $Q E$ programs emerged in the USA during the 2007-2008 financial crisis. Since the beginning of the global crisis, the Federal Reserve has launched several rounds of QE. The Fed began to increase its balance sheet by buying government bonds and mortgage-backed securities. The first round of QE began in November 2008. The Fed has offered to buy 100 billion USD in bonds from Freddie Mac, Fannie Mae and Ginnie Mae. In November 2010, the Fed announced another bond purchase program, QE2. In September 2011, the Fed launched a new program called Operation Twist. In January 2013, it launched QE3. Three QE programs were implemented in the United States from 2008 to 2015 , resulting in an increase in the balance of the Federal Reserve System from approximately 1 trillion USD to 4.5 trillion USD (see Figure 5)

The Bank of England followed suit in 2009 by purchasing sovereign bonds and highquality corporate bonds worth over 200 billion GBP, followed by other asset acquisition programs, which totaled 375 billion GBP in 2012.

Quantitative easing (QE) was launched by the European Central Bank in March 2015 to prevent further inflation from dropping below zero. The economy was still experiencing the euro area debt crisis. The ECB has spent 2.6 trillion EUR over almost four years, buying mainly government and corporate debt. As expected, QE increased economic growth, while wages and lending increased, but inflation remained low (see Figure 4). This complicates the exit from QE and ensures that interest rates will remain at record lows for some time.
The overall expansion of central bank balances as a result of this monetary policy is in the range of 11 trillion USD between 2008 and 2018 (this includes data for the United States, Japan, the euro area). The total size of the Joint Balance Sheets is currently 15 trillion USD, or about 20 percent of the world's gross domestic product (GDP). Through this process, central banks have become key holders of bonds.

\section{Conclusions}

Quantitative easing (QE) is a monetary policy that considers central bank bonds and other newly created debt instruments. Central banks buy government debt (sovereign bonds) - as well as corporate bonds. This leads to an exchange: investors sell their bonds to the central bank and receive money in return. Thus, central banks accumulate bonds and investorsincrease their funds. $\mathrm{QE}$ is likely to apply only when the effectiveness of monetary policy is low, suggesting that it needs to be aggressively and decisively deployed to have the desired effect. The ECB has implemented a quantitative easing policy between 2015 and 2018. Japan conducted QE 2001-2006 operations and from 2012 to the present, US 2008-2014. Initially, the programs were aimed at solving the problems of the financial market, but soon this goal has expanded and now includes reaching inflation targets, stimulating the real economy and curbing Europe's sovereign debt crisis. The economies of these countries are recovering, but the question remains whether this is due to such an aggressive policy and how effective it is. 


\section{References:}

Andrade, P., Breckenfelder, J., De Fiore, F., Karadi, P., \& Tristan, O. (2016). The ECB's asset purchase programme: an early assessment Working Paper of the European Central Bank No 1956.

Dell'Ariccia, G., Rabanal, P., \& Sandri, D. (2018). Unconventional Monetary Policies in the Euro Area, Japan, and the United Kingdom International Monetary Fund (IMF) Hutchins Center Working Paper № 48.

Fawley, B. W., \& Neely, C. J. (2013). Four Stories of Quantitative Easing The Federal Reserve Bank Fernandez, R., Bortz, P., \& Zeolla, N. (2018). The politics of quantitative easing. SOMO Amsterdam.

Filardo, A., \& Nakajima, J. (2018). Effectiveness of unconventional monetary policies in a low interest rate environment. BIS Working Papers No 691.

Haldane, A., Sklar, M. R., Wieladek, T., \& Young, C. (2016). QE: The Story so Far. Bank of England Working Paper No. 624. Available at SSRN: https://ssrn.com/abstract=2858204

IMF. Available at: https://www.imf.org/

Martin F. (2012). The Failure of the Euro. The Foreign Affairs.

Neuenkirch, M. (2016). An Unconventional Approach to Evaluate the Bank of England's Asset Purchase Program. Open Economies Review.

Yardeni Research (2018). Global economic briefing: Central banks' balance sheets. 